\title{
New insights on the interaction mechanism of rhTNF $\alpha$ with its antagonists Adalimumab and Etanercept.
}

María Angélica Contreras ${ }^{1,2}$, Luis Macaya ${ }^{2}$, Pedro Neira ${ }^{1}$, Frank Camacho ${ }^{1}$, Alaín González ${ }^{1}$, Jannel Acosta $^{3}$, Raquel Montesino ${ }^{3}$, Jorge Roberto Toledo ${ }^{2,3}$, Oliberto Sánchez ${ }^{1,2, *}$.

${ }^{1}$ Recombinant Biopharmaceuticals Laboratory, Pharmacology Department, School of Biological Sciences, Universidad de Concepción, Victor Lamas 1290, P.O. Box 160-C, Concepción, Chile.

${ }^{2}$ Center for Biotechnology and Biomedicine Spa., Chile.

${ }^{3}$ Biotechnology and Biopharmaceutical Laboratory, Pathophysiology Department, School of Biological Sciences, Universidad de Concepción, Victor Lamas 1290, P.O. Box 160-C, Concepción, Chile.

*Corresponding author: Oliberto Sánchez Ramos Ph.D.

E-mail: osanchez@udec.cl

Running title: News about TNF $\alpha$-binding of Adalimumab and Etanercept.

Keywords: Tumor necrosis factor (TNF), protein purification, antibody, protein-protein interaction, microscale thermophoresis (MST), autoimmune disease. 


\begin{abstract}
$\mathrm{TNF} \alpha$ is a pro-inflammatory cytokine that is a therapeutic target for inflammatory autoimmune disorders. Thus, TNF $\alpha$ antagonists are successfully used for the treatment of these disorders. Here, new association patterns of rhTNF $\alpha$ and its antagonists Adalimumab and Etanercept are disclosed. Active rhTNF $\alpha$ was purified by IMAC from the soluble fraction of transformed E. coli. Protein detection was assessed by SDS-PAGE and western blot. The $\mathrm{K}_{\mathrm{D}}$ values for rhTNF $\alpha$ interactions with their antagonists were obtained by non-competitive ELISA and by microscale thermophoresis. Molecular sizes of the complexes were characterized by SEC-HPLC. Surprisingly, both antagonists recognized the monomeric form of rhTNF $\alpha$ under reducing and non-reducing conditions, indicating unexpected bindings of the antagonists to lineal epitopes and to one protomer of rhTNF $\alpha$. Binding curves of two phases with low and high $\mathrm{K}_{\mathrm{D}}$ values $\left(<10^{-9} \mathrm{M}\right.$ and $>10^{-8} \mathrm{M}$ ) were observed during thermophoresis experiments, suggesting the generation of complexes with different stoichiometry, which were confirmed by SEC-HPLC. This pioneer investigation revealed interactions of rhTNF $\alpha$ with Adalimumab and Etanercept never described before, which constitute valuable data for future approaches into the study of their interaction mechanism.
\end{abstract}

\section{Introduction}

Tumor necrosis factor alpha (TNF $\alpha)$ is a pleiotropic cytokine that promotes inflammation and immune response (1). TNF $\alpha$ is produced by cells of the immune system as a transmembrane protein arranged in homotrimers (2), and a soluble form of TNF $\alpha$ is also generated by proteolytic cleavage (3). Trimeric forms of $\mathrm{TNF} \alpha$ interact with the receptors TNF-R1 and TNF-R2, and activate intracellular signaling (4, 5). Different processes involved in inflammation are mediated by TNF $\alpha$, such as the expression of adhesion molecules in endothelial cells, the recruitment of immune cells to injury sites, the production of other inflammatory cytokines (IL1, IL-6, IL-17), among others (6).

Although TNF $\alpha$ has an important physiological function in the immune response, it is known that the uncontrolled production or function of this cytokine are related to inflammatory autoimmune diseases, such as rheumatoid arthritis, psoriasis, inflammatory bowel disease, ankylosing spondylitis, and others $(7,8)$. Thus, $\mathrm{TNF} \alpha$ is the main therapeutic target for these diseases, and its inhibition by biopharmaceuticals has been used as a successful treatment against them $(6,7)$.

Currently, the anti-TNF $\alpha$ biopharmaceuticals in the market are the monoclonal antibodies Infliximab, Adalimumab, and Golimumab. Also, a soluble TNF-R2 receptor named Etanercept, and a pegylated antibody fragment named Certolizumab pegol are available (9). Several researches have determined the interaction of $\mathrm{TNF} \alpha$ and its antagonists. The crystalline structures of the complexes TNF $\alpha$-Infliximab (10), TNF $\alpha$-Adalimumab (11), TNF $\alpha$ Golimumab (12) and TNF $\alpha$-Certolizumab pegol (13) have been resolved. The structure of the complex TNFR2-TNF $\alpha$ was already disclosed (14), which is supposed to be similar to the interaction between Etanercept and TNF $\alpha$ (15, 16). The interaction among $\mathrm{TNF} \alpha$ and every antagonist mentioned above are mainly with conformational epitopes. Two protomers of the TNF $\alpha$ homotrimer conform the binding epitopes for Adalimumab and Etanercept, while the epitopes for Infliximab, Golimumab and Certolizumab pegol are composed by residues from one protomer. Moreover, the dissociation constants $\left(\mathrm{K}_{\mathrm{D}}\right)$ of these complexes were determined by Surface Plasmon Resonance (SPR) in several reports (17-19), corroborating the high affinity among the TNF $\alpha$ and the biopharmaceuticals.

All TNF $\alpha$ antagonists bind and neutralize the activity of the cytokine $(6,15)$. However, the biopharmaceuticals have demonstrated distinct effectiveness in the treatment of different inflammatory diseases. These discrepancies have been explained by differences in the binding site and the interaction type among $\mathrm{TNF} \alpha$ and its antagonists, and by the effector functions of each molecule $(6,15,20)$. The use of other experimental approaches and new techniques could provide novel information about the nature of these bindings. Therefore, the aim of this paper was to study the interactions between TNF $\alpha$-Adalimumab and TNF $\alpha$-Etanercept using immunodetection methods, microscale 
thermophoresis (MST) and size-exclusion chromatography-High performance liquid chromatography (SEC-HPLC). We produced active recombinant human $\mathrm{TNF} \alpha(\mathrm{rhTNF} \alpha)$ in the E. coli strain SHuffle ${ }^{\circledR}$ T7 Express, and the interactions of rhTNF $\alpha$ with Adalimumab and Etanercept were studied. Our main findings were that Adalimumab and Etanercept recognized monomers and lineal epitopes of rhTNF $\alpha$. Also, the two-phase binding curves observed by microscale thermophoresis and the results of SEC-HPLC confirmed the formation of different molecular weights complexes for AdalimumabrhTNF $\alpha$ and Etanercept-rhTNF $\alpha$.

\section{Results}

\section{Production of active $\operatorname{rhTNF} \alpha$}

After expressing the rhTNF $\alpha$ in the E. coli strain SHuffle ${ }^{\circledR}$ T7 Express, it was purified by immobilized metal affinity chromatography (IMAC). SDS-PAGE and western blot showed that most of the contaminant proteins were eliminated in the unbounded material and in the wash fractions. Elution showed band of protein around $17-\mathrm{kDa}$ with a $92 \%$ purity (Figure 1 ).

The rhTNF $\alpha$ biological activity was confirmed by an in vitro cytotoxicity assay in L929 cells. The cell viability diminished with increasing concentrations of rhTNF $\alpha$, similar effects were observed for the recombinant human TNF $\alpha$ (Merck, Germany) when it was used as positive control. The values of $\mathrm{EC}_{50}$ were $221.8 \mathrm{pg} / \mathrm{ml}$, and $1012 \mathrm{pg} / \mathrm{ml}$ for the $\mathrm{rhTNF} \alpha$ and for the positive control, respectively (Figure 2A).

To confirm that the reduction of the cell viability caused by the rhTNFa was not due to contaminant proteins, Adalimumab and Etanercept were used to neutralize the cytotoxicity induced by the rhTNFa. The rhTNF $\alpha$ cytotoxicity was totally neutralized with Adalimumab and Etanercept. The Adalimumab $\mathrm{EC}_{50}$ was $78.6 \mathrm{ng} / \mathrm{ml}$, and the Etanercept $\mathrm{EC}_{50}$ was $71.2 \mathrm{ng} / \mathrm{ml}$ (Figure 2B). The cytotoxicity neutralization in L929 cells confirmed that the reduction in the cell viability was only due to the rhTNF $\alpha$ activity.

Binding characterization of rhTNF $\alpha$ and its antagonists by immunodetection techniques
The binding among the rhTNFa and its antagonists was detected by native PAGE, SDSPAGE and western blot in different conditions. The Native PAGE of rhTNF $\alpha$ showed two bands of proteins (Figure 3A), which were recognized by the anti-6xHis Tag antibody in the western blot assay. These bands and an additional one were immuno-identified by Adalimumab and Etanercept (Figure 3B).

Also, the rhTNF $\alpha$ was analyzed by SDS-PAGE and western blot under reducing and nonreducing conditions. The SDS-PAGE and the Coomassie blue stain showed different bands and the reinforced band of around $17 \mathrm{kDa}$ corresponded to rhTNF $\alpha$ monomers (Figure 3C). The western blot assays showed that the anti6xHis antibody, Adalimumab and Etanercept recognized rhTNF $\alpha$ monomers in reducing and non-reducing conditions. Additionally, a band of around $35 \mathrm{kDa}$ was also detected by Adalimumab and Etanercept. It could correspond to dimers of the rhTNF $\alpha$ in nonreducing conditions (Figure 3D).

The Beatty and Beatty approach (21) was used to determine the $\mathrm{K}_{\mathrm{D}}$ of Adalimumab-rhTNF $\alpha$ and Etanercept-rhTNF $\alpha$ interactions in a noncompetitive enzymatic immunoassay. The $\mathrm{K}_{\mathrm{D}}$ determination of this method require the calculations of the $\mathrm{OD}_{50}$ at two concentrations of the rhTNF $\alpha$. The $\mathrm{OD}_{50}$ for Adalimumab at 1,25 and $2,5 \mu \mathrm{g} / \mathrm{ml}$ of $\mathrm{rhTNF} \alpha$ were $0.641 \mathrm{nM}$ and $0.622 \mathrm{nM}$, respectively. The $\mathrm{K}_{\mathrm{D}}$ for the interaction of TNF $\alpha$-Adalimumab was $1.32 \mathrm{nM}$ (Figure 4A). For Etanercept-rhTNFa, the $\mathrm{OD}_{50}$ using the above concentrations of the rhTNFa were $1.035 \mathrm{nM}$ and $1.072 \mathrm{nM}$, and the $\mathrm{K}_{\mathrm{D}}$ for the interaction was $1.99 \mathrm{nM}$ (Figure 4B).

\section{Microscale thermophoresis and SEC-HPLC of rhTNF $\alpha$ and its antagonists.}

For studying the interaction of rhTNF $\alpha$ Adalimumab and rhTNF $\alpha$-Etanercept by MST, it is required the labeling of one molecule in each pair of interaction. As the labeling could alter the ligand binding, two MST experiments was performed for each interaction partners. One by labeling rhTNF $\alpha$ and the other by labeling the antagonist. The rhTNF $\alpha$ and Etanercept were labeled in the amine groups (NHS-coupling). However, Adalimumab was labeled in the thiol groups (Cys-coupling) because any interaction 
was detected when it was labeled in the amine groups (not shown).

Two MST experiments were performed to study the interaction rhTNF $\alpha$-Adalimumab. First, the MST was performed using a fluorescent-labeled Adalimumab (Cys-coupling) and rhTNFa without labeling. A binding curve was obtained with a $\mathrm{K}_{\mathrm{D}}$ value of $29.6 \pm 7.4 \mathrm{nM}$ (Figure 5A). A second experiment was performed using the rhTNF $\alpha$ labeled in the amine groups and Adalimumab without labeling. A two-phases equilibrium was observed. At concentrations of Adalimumab from $30.5 \mathrm{pM}$ to $7.8 \mathrm{nM}$, a $\mathrm{K}_{\mathrm{D}}$ value of $100.2 \pm 187.5 \mathrm{pM}$ was determined, and for Adalimumab concentrations from 1.95 to 1 $\mu \mathrm{M}$, we obtained a $\mathrm{K}_{\mathrm{D}}$ value of $21.00 \pm 9.43 \mathrm{nM}$ (Figure 5B).

The evaluation of the interaction rhTNFaEtanercept with a similar approach was performed. A two-phase pattern was observed when Etanercept labeled in the amino groups and non-labeled rhTNF $\alpha$ were used. A $K_{D}$ value of $1.25 \pm 0.78 \mathrm{nM}$ was obtained at concentrations of the rhTNF $\alpha$ from $19.1 \mathrm{pM}$ to $39.1 \mathrm{nM}$. At rhTNF $\alpha$ concentrations from $4.88 \mathrm{nM}$ to $20 \mu \mathrm{M}$, a $K_{D}$ value of $175.5 \pm 38.2 \mathrm{nM}$ was detected (Figure 5C). Finally, the interaction rhTNF $\alpha-$ Etanercept was analyzed using labeled rhTNFa and unlabeled Etanercept. Also, a two-phases equilibrium was detected. The first curve had a $\mathrm{K}_{\mathrm{D}}$ value of $317.8 \pm 325.3 \mathrm{pM}$, and it involved Etanercept concentrations from $38.1 \mathrm{pM}$ to 39.1 $\mathrm{nM}$. The second curve had a $\mathrm{K}_{\mathrm{D}}$ value of $183.5 \pm$ $23.4 \mathrm{nM}$ when concentrations of Etanercept from $1.22 \mathrm{nM}$ to $1.25 \mu \mathrm{M}$ were evaluated (Figure 5D). To corroborate that multiple equilibria detected by MST were due to the formation of complexes with different compositions, samples containing distinct molar ratios of rhTNF $\alpha$ and its antagonists were analyzed by SEC-HPLC. When Adalimumab and rhTNFa were mixed at equimolar concentration, complexes with retention times (RT) between $11 \mathrm{~min}$ and $18 \mathrm{~min}$ were detected with molecular weight up to 600 $\mathrm{kDa}$, approximately (Figure 6B). When an excess of Adalimumab or rhTNFa were analyzed, we detected the molecule excess and species with variable weights. The Adalimumab excess showed a signal at $17.5 \mathrm{~min}$, which corresponded to complexes of around $650 \mathrm{kDa}$ (Figure 6C). The rhTNF $\alpha$ excess displayed peaks at 17.8 and $19.5 \mathrm{~min}$, which agreed with complexes of molecular weights around 625 and $403 \mathrm{kDa}$, respectively (Figure 6D).

The same methodology was used to analyze the interaction between Etanercept and rhTNF $\alpha$. The Etanercept-rhTNF $\alpha$ interaction at the same concentration showed a wider and asymmetric peak compared to the control, and the signal of rhTNF $\alpha$ was not observed (Figure 7B), meaning that all rhTNF $\alpha$ was bound to Etanercept. When an excess of Etanercept was evaluated, only its signal was detected (Figure 7C), and the rhTNF $\alpha$ excess revealed three peaks at $17.2 \mathrm{~min}$ (up to $669 \mathrm{kDa}$ ), $19.2 \mathrm{~min}$ (around $453 \mathrm{kDa}$ ) and $23 \mathrm{~min}$ (rhTNF $\alpha$ excess) (Figure 7D).

\section{Discussion}

$\mathrm{TNF} \alpha$ is an important pro-inflammatory cytokine for the immune response. It also has a critical role in inflammatory autoimmune disorders, and the inhibition of TNF $\alpha$ with biopharmaceuticals constitute an effective treatment for them. Adalimumab and Etanercept are the most sold biopharmaceuticals (22), which are two different types of TNF $\alpha$ antagonists. Adalimumab is a human monoclonal antibody (IgG1), and Etanercept is a fusion protein based on the extracellular domain of the human TNF$\mathrm{R} 2$ and the Fc fragment of human IgG1 (6). Here, active rhTNF $\alpha$ was produced in E. coli, and its interaction with Adalimumab and Etanercept was studied. The main findings were: 1) Adalimumab and Etanercept recognize rhTNF $\alpha$ monomers, even under denaturant and reducing conditions, suggesting that these molecules could recognize linear epitopes in rhTNF $\alpha$; 2) At different concentrations of rhTNFa, Adalimumab and Etanercept, complexes with diverse stoichiometry are formed.

Soluble hTNF $\alpha$ is a $51 \mathrm{kDa}$ trimer, which has been described as a necessary condition for its biological activity (5). Here, we produced rhTNF $\alpha$ with similar activity to that reported elsewhere $(23,24)$. It was used for all experimental procedures.

The interaction between TNF $\alpha$ and biopharmaceuticals has been studied in several reports using different techniques and approaches. The reported crystal structure of the complex TNF $\alpha$-Adalimumab (PDB code: 3 WD5) revealed that the antibody recognized a conformational epitope in $\mathrm{TNF} \alpha$, which is 
composed by residues from two protomers of the protein (Figure 8A) (11). Considering the structure for the TNF $\alpha$-TNFR2 complex (PDB code: 3ALQ), it is expected that Etanercept interact with TNF $\alpha$ in the groove formed by two protomers (Figure 8B) (14). However, we observed that Adalimumab and Etanercept recognized rhTNF $\alpha$ monomers in western blot assays after denaturant electrophoresis in reducing and non-reducing conditions. This is the first study that reports the interaction of Adalimumab and Etanercept with $\mathrm{TNF} \alpha$ monomers and lineal epitopes.

Analyzing the TNF $\alpha$-Adalimumab interphase of the crystal structure (11), five linear aminoacidic sequences were detected in TNF $\alpha: \mathrm{K}_{65}-\mathrm{G}_{66}-\mathrm{Q}_{67}$, $\mathrm{K}_{90}-\mathrm{V}_{91}-\mathrm{N}_{92}, \quad \mathrm{E}_{110}-\mathrm{A}_{111}-\mathrm{K}_{112}-\mathrm{P}_{113}, \quad \mathrm{E}_{135}-\mathrm{I}_{136}-\mathrm{N}_{137}$ and $\mathrm{A}_{145}-\mathrm{E}_{146}-\mathrm{S}_{147}$ (Figure 8A). These sequences could be recognized by Adalimumab in denaturant and reducing conditions. Also, mutations of $\mathrm{K}_{65}, \mathrm{Q}_{67}, \mathrm{E}_{135}$, and $\mathrm{E}_{146}$ by alanine residues generates a 100-fold decrease in the affinity of Adalimumab for its target (11), which confirms the importance of these residues for the TNF $\alpha$-Adalimumab interaction. On the other hand, the analysis of the TNF $\alpha$-Etanercept interface showed the sequence $\mathrm{D}_{143}-\mathrm{F}_{144}-\mathrm{A}_{145}$ $\mathrm{E}_{146}$ (Figure 8B), which forms the G-H loop in $\mathrm{TNF} \alpha$ and is crucial to the interaction with the Cysteine Rich Domain 2 (CRD2) of TNF-R2 (14). This sequence could be recognized by Etanercept when rhTNF $\alpha$ was run under denaturant and reducing conditions.

As a new approach to study the interactions of rhTNF $\alpha$ with Adalimumab and Etanercept, we used the microscale thermophoresis (MST). This methodology is based on the motion of molecules in microscopic temperature gradients generated in a free fluid. It is an easy and rapid technique, which requires low sample quantities and there are no limitations of molecular weight or size when the interactions are measured. Additionally, the $\mathrm{K}_{\mathrm{D}}$ of a wide binding variety can be detected in the equilibrium stage by titration experiments $(25,26)$. Our MST analysis revealed equilibria in two phases. At low molar ratios, we detected low $K_{D}$ values for both complexes (rhTNF $\alpha$-Adalimumab, rhTNF $\alpha$ Etanercept) in the first phase of the binding curves, which were consistent with the $K_{D}$ values previously reported $(17-19,27,28)$. The second phase of the binding curves obtained at high ligand concentration were unexpected. We postulated that these high $\mathrm{K}_{\mathrm{D}}$ values corresponded to the formation of complexes with a stoichiometry higher than 1:1 among rhTNF $\alpha$ and its antagonists. Indeed, complexes of high molecular weights were detected by SEC-HPLC. The interaction between rhTNFa and Adalimumab showed complexes higher than 600 $\mathrm{kDa}$. Previous reports have detected the formation of complexes $1: 1,1: 2,2: 2$, and $3: 2$ ratios of Adalimumab:TNF $\alpha$ by electron microscopy (29). Moreover, complexes of 4.000 $\mathrm{kDa}$ were described by SEC-LS (30). Proposed complexes of Adalimumab-TNF $\alpha$ are presented in the Figure 8C. Additional structures of higher molecular weights could be formed taking into account the multiple sites of interaction available in each molecule, and the flexibility that the hinge region of Adalimumab could provide to the complexes.

Although, the formation of the complex TNF $\alpha$ Etanercept 1:2 was reported previously when 3fold Etanercept over TNF $\alpha$ was evaluated by SEC-LS (30), it is generally assumed that one Etanercept bound one TNF $\alpha$ trimer $(19,20)$. We observed complexes higher than $400 \mathrm{kDa}$ by SEC-HPLC. Unlike the interaction of rhTNFaAdalimumab, complexes of high molecular weight (sizes up to $2.000 \mathrm{kDa}$ ) were not detected for rhTNF $\alpha$-Etanercept. Considering the results of MST and SEC-HPLC, we hypothesized that complexes TNF $\alpha$-Etanercept 2:1 might be formed when an excess of TNF $\alpha$ was added, while complexes 1:2 could be formed when there was an excess of Etanercept. Schemes of these complexes are presented in Figure 8D. The rigid structure of Etanercept could prevent the formation of high molecular weight complexes. Our results demonstrated that the binding of rhTNFa with Adalimumab and Etanercept involve the formation of higher structures when an excess of ligand is added. Under these conditions, $\mathrm{K}_{\mathrm{D}}$ values of rhTNF $\alpha$-Adalimumab complexes were ten-fold lower than that of rhTNF $\alpha$-Etanercept complexes. This data could suggest that the assembly of rhTNF $\alpha$ Adalimumab complexes are favored compared to rhTNF $\alpha$-Etanercept complexes. It also could be related to the individual structures of Adalimumab and Etanercept.

Under physiological and pathophysiological contexts, $\mathrm{TNF} \alpha$ concentrations in serum are 
around $10 \mathrm{pg} / \mathrm{ml}\left(2 \times 10^{-12} \mathrm{M}\right)(31,32)$. The Adalimumab and Etanercept concentrations in serum range from 1 to $8 \mu \mathrm{g} / \mathrm{ml} \quad\left(6.7 \times 10^{-9}\right.$ to $\left.5,3 \times 10^{-8} \mathrm{M}\right)(33-37)$. The levels of these molecules suggest that the complexes mentioned above could not be formed. However, the accumulation of these molecules in the inflammation sites could favor the formation of high molecular weight complexes. Still, it has not been reported and the relevance of this issue is uncertain.

Overall, novel interaction of rhTNF $\alpha$ with Adalimumab and Etanercept were described. Further studies must be conducted to elucidated if the formation of higher complexes could be relevant for future therapeutic approaches.

\section{Experimental procedures}

\section{Reagents and antibodies.}

Chemical compounds were provided by Merck and Sigma-Aldrich. Restriction enzymes were purchased from New England Biolabs. Recombinant human TNFa (GF023) was from Merck. Purified anti-His tag mouse antibody was from BioLegend (USA). Secondary antibodies Alexa Fluor ${ }^{\circledR} 680$ AffiniPure Donkey anti-mouse IgG and Alexa Fluor ${ }^{\circledR} 790$ AffiniPure Donkey Anti-human IgG $(\mathrm{H}+\mathrm{L})$ were obtained from Jackson ImmunoResearch Inc (USA), and anti-Human IgG (Fc specific) -Peroxidase antibody produced in goat was from Sigma-Aldrich. Two TNF $\alpha$-antagonists were purchased: Adalimumab (Humira ${ }^{\circledR}$, Abbie) and Etanercept (Enbrel ${ }^{\circledR}$, Pfizer).

\section{Construction of expression vector.}

The DNA sequence codifying the soluble human $\mathrm{TNF} \alpha$ (residues 85-233 from UniProt P01375) was sub-cloned into a pET-22b $(+)$ vector at the XhoI and NdeI sites, generating pET-22bhTNF $\alpha$ vector. The pET-22b-hTNF $\alpha$ vector permits the TNF $\alpha$ expression under the control of $\mathrm{T} 7$ promoter, and it is inducible using isopropyl- $\beta$-D-thiogalactopyranoside (IPTG). Furthermore, the gene of TNF $\alpha$ is in frame with a C-terminal His $\bullet$ Tag ${ }^{\circledR}$ to facilitate the detection and purification of recombinant protein.

\section{Recombinant hTNF $\alpha$ obtention.}

SHuffle ${ }^{\circledR}$ T7 Express chemically competent $E$. coli (New England Biolabs, England) were transformed with pET-22b-hTNF $\alpha$ vector and selected in LB medium supplemented with 100 $\mu \mathrm{g} / \mathrm{ml}$ ampicillin (US Biological, USA). A clone of transformed bacteria was grown in liquid LBAmpicillin medium at $30^{\circ} \mathrm{C}$ until O.D. $600 \mathrm{~nm}$ 0.8; IPTG (US Biological, USA) was added to a final concentration of $0.1 \mathrm{mM}$. After six hours, bacteria were collected by centrifugation at $6.000 \mathrm{~g}$ and resuspended in $50 \mathrm{mM}$ Tris- $\mathrm{HCl} \mathrm{pH}$ 7.5. Then, cells were disrupted in an EmulsiflexC5 homogenizer (Avestin, Canada); soluble and insoluble fractions were separated by centrifugation $\left(28960 \mathrm{~g}, \quad 4^{\circ} \mathrm{C}, 30 \mathrm{~min}\right)$. Immobilized Metal Affinity Chromatography (IMAC) was performed for protein purification using an AKTA Start Chromatography system (GE Healthcare Bio-Science, Sweden). The soluble fraction containing $\mathrm{TNF} \alpha$ was diluted (1:1) with equilibrium buffer $(50 \mathrm{mM}$ Tris, $5 \mathrm{mM}$ Imidazole, $300 \mathrm{mM} \mathrm{NaCl}, \mathrm{pH} \mathrm{7.5)}$ and was applied to Ni-charged chelating Sepharose Fast Flow column (GE Healthcare Bio-Science, Sweden). After that, the column was washed with $50 \mathrm{mM}$ Tris- $100 \mathrm{mM}$ Imidazole- $300 \mathrm{mM}$ $\mathrm{NaCl} \mathrm{pH} 7.5$, and the recombinant protein was eluted with $50 \mathrm{mM}$ Tris- $300 \mathrm{mM}$ Imidazole- 300 $\mathrm{mM} \mathrm{NaCl} \mathrm{pH}$ 7.5. An Amicon Ultra-15 Centrifugal Filter Unit 3kDa (Merck, Germany) was used to concentrate elution fraction containing rhTNF $\alpha$ and exchange the buffer to PBS $1 \mathrm{X} \mathrm{pH} \mathrm{7.4.} \mathrm{The} \mathrm{total} \mathrm{protein} \mathrm{concentration}$ was determined using BCA protein assay kit (Thermo Fisher Scientific, USA). The purity percentage of rhTNF $\alpha$ was calculated by densitometry using freely available ImageJ software (NIH Image, USA).

\section{Electrophoresis and western blot analysis.}

For the detection of rhTNF $\alpha, 5 \mu \mathrm{g}$ of protein were loaded on $15 \%$ SDS-PAGE, and $8 \mu \mathrm{g}$ of protein were loaded on $12 \%$ native-PAGE. Protein electrophoresis was conducted according to the standard methods (38). The native-PAGE was run using the protocol similar to SDS-PAGE except for the absence of SDS in the loading buffer, the running buffer, and the gel. Gels were stained with Coomassie Blue (Phast Gel TM Blue R, GE Healthcare, Sweden).

For western blot, proteins were transferred to 0.2 $\mu \mathrm{m}$ nitrocellulose membranes (GE Healthcare Life science, Germany) in a semi-dry transfer system (Bio-Rad, USA). The membranes were 
blocked with 5\% skim milk in TBS for $2 \mathrm{~h}$ at room temperature. Primary antibodies (anti-His Tag mouse antibody, Adalimumab and Etanercept) were prepared in TBS containing 2\% skim milk, and the membrane was incubated for $2 \mathrm{~h}$ with the preparation. Membranes were washed three times and incubated for $1 \mathrm{~h}$ with secondary antibodies conjugated with a fluorophore (anti-mouse IgG- Alexa Fluor 680 and anti-human IgG- Alexa Fluor 790). The blots were detected and digitalized using the Odyssey infrared imaging system (LI-COR Biosciences, USA).

\section{L929 cytotoxicity assay.}

L929 cells (ATCC) were seeded in 96-well plate at a $3 \times 10^{4}$ cells per well density and were cultured in RPMI-1640 medium (Biological Industries, Israel) containing $10 \%$ FBS (Biological Industries, Israel) and $50 \mu \mathrm{g} / \mathrm{ml}$ Neomycin (Sigma-Aldrich, Switzerland) with $5 \% \mathrm{CO}_{2}$ at $37^{\circ} \mathrm{C}$. The cells were incubated for 24 $\mathrm{h}$ to allow attachment. Then the culture medium was removed and replaced with RPMI medium containing $1 \mu \mathrm{g} / \mathrm{ml}$ D-Actinomycin (Merck, Germany) and different samples of rhTNF $\alpha$ or rhTNF $\alpha$ incubated with TNF $\alpha$ antagonist. Cells were treated for $20 \mathrm{~h}$, and cell viability was determined by MTT assay (39) . To MTT assay, the medium was replaced with $110 \mu 1$ per well of RPMI containing $0.45 \mathrm{mg} / \mathrm{ml}$ MTT (Thermo Fisher Scientific, USA). After $4 \mathrm{~h}$ of incubation at $37^{\circ} \mathrm{C}$ in darkness, supernatants were removed carefully, and $100 \mu \mathrm{l}$ of isopropanol was added to each well for dissolve formazan crystals. The absorbance was recorded at $570 \mathrm{~nm}$ in a Synergy ${ }^{\text {TM }}$ HTX Multi-Mode Microplate Reader (BioTek). Results were represented as cells viability percent $(\% \mathrm{~V})$ calculated as $\% \mathrm{~V}=(\mathrm{O} . \mathrm{D}$. test group/O.D. control group) x100. Mathematical analysis was performed using Graph Pad Prism 7 software.

\section{Enzyme Immunoassay.}

The wells of a high binding 96-well plate were coated with $100 \mu \mathrm{l}$ of TNF $\alpha$ at 1.25 and $2.5 \mu \mathrm{g} / \mathrm{ml}$ in coating buffer $\mathrm{pH} 9.6$ at $4^{\circ} \mathrm{C}$ overnight, and blocked with $200 \mu \mathrm{l}$ blocking buffer (3\% BSA in PBS) at $37^{\circ} \mathrm{C}$ for $2 \mathrm{~h}$. Samples of different concentrations of anti-TNF $\alpha$ molecules Adalimumab and Etanercept (200 nM to 12,2 $\mathrm{pM}$ ) were applied in wells and incubated at $25^{\circ} \mathrm{C}$ for $1 \mathrm{~h}$. Then, the wells were washed with PBS$0.1 \%$ Tween 20 for three times; $100 \mu \mathrm{l}$ of peroxidase-conjugated anti-human IgG antibody dissolved 1:5.000 in 1\% BSA-PBS were added to each well. After $1 \mathrm{~h}$, wells were washed with PBS-0.1\% Tween 20, and $100 \mu$ of a solution containing OPD (Santa Cruz Biotechnology Inc.) was added to each well. The reaction was left to develop in the dark and was stopped with $2.5 \mathrm{M} \mathrm{H}_{2} \mathrm{SO}_{4}$. Finally, the absorbance was recorded at $492 \mathrm{~nm}$ in a Synergy ${ }^{\mathrm{TM}}$ HTX MultiMode Microplate Reader (BioTek). Mathematical analysis was performed using Graph Pad Prism 7 software.

\section{Microscale Thermophoresis.}

The MST experiments were performed in a Monolith NT.115 Pico (NanoTemper Technologies, Germany) using the Monolith Protein Labeling Kit RED-NHS (Amine Reactive), the Monolith Protein Labeling Kit RED-NHS 2nd Generation (Amine Reactive), the Monolith Protein Labeling Kit REDMaleimide (Cysteine Reactive), and the Monolith NT.115 Premium Capillaries (NanoTemper Technologies, Germany).

For experiments with labeled rhTNF $\alpha$ (Amine Reactive) and TNF $\alpha$-antagonists, we have kept the concentration of NT-650 labeled rhTNFa constant $(2 \mathrm{nM})$. In contrast, the concentration of Etanercept was varied between $1.25 \mu \mathrm{M}-38.1$ $\mathrm{pM}$ and the concentration of Adalimumab was varied between $1 \mu \mathrm{M}-30.5 \mathrm{pM}$. The assays were performed in PBS containing Tween-20 0.05\%, at $40 \%$ of excitation power, and $40 \%$ of MST power. MST traces were analyzed at 5 seconds. For performing experiments with labeled Adalimumab, a fluorescent label (NT-647) was covalently attached to the protein (Cysteine Reactive). In the experiment, the concentration of labeled Adalimumab was constant ( $5 \mathrm{nM}$ ), while the concentration of rhTNF $\alpha$ was varied between $500 \mathrm{nM}-30.5 \mathrm{pM}$. The assay was performed in the buffer provided by the manufacturer containing Tris- $\mathrm{HCl} 50 \mathrm{mM} \mathrm{pH}$ 7.4, $\mathrm{NaCl} 150 \mathrm{mM}, \mathrm{MgCl}_{2} 10 \mathrm{mM}$, and Tween$200.05 \%$. After a short incubation, the samples were loaded into MST NT.115 hydrophilic glass capillaries. The experiment was performed at $20 \%$ of excitation power and $40 \%$ of MST power. MST traces were analyzed at 1.5 seconds. 
For performing experiments with NT-647 labeled Etanercept (Amine Reactive), the concentration of labeled Etanercept was constant $(2 \mathrm{nM})$ while the concentration of rhTNF $\alpha$ was varied between $20 \mu \mathrm{M}-19.1 \mathrm{pM}$. The assay was performed in PBS containing 0.05\% Tween-20. After a short incubation, the samples were loaded into premium glass capillaries. The experiment was performed at $10 \%$ of excitation power and $40 \%$ of MST power. MST traces were analyzed at 2.5 seconds.

The results were analyzed in the software M.O. Affinity Analysis v.2.3 (NanoTemper Technologies, Germany).

\section{Size exclusion chromatography-High performance liquid chromatography (SEC- HPLC).}

Samples of Adalimumab, Etanercept, rhTNFa and mixtures of them were analyzed using a Jasco system (Japan) with a TSK Gel $\mathrm{G} 4000 \mathrm{SW}_{\mathrm{XL}}$ column $(7.8 \mathrm{~mm}$ I.D. $\mathrm{x} 30 \mathrm{~cm})$ (Tosoh Bioscience, Japan). The chromatographic analyses were performed with a flow rate of $0.5 \mathrm{ml} / \mathrm{min}$ and using a $50 \mathrm{mM}$ phosphate-300 $\mathrm{mM} \mathrm{NaCl}$ buffer ( $\mathrm{pH} 7.5$ ) at room temperature. The detection was performed on a Jasco 2075 Plus UV detector (Jasco, Japan) at $280 \mathrm{~nm}$. The Gel Filtration Calibration Kits (LMW, HMW) (GE Healthcare Life science, Germany) were utilized.

\section{ACKNOWLEDGMENTS}

The authors are thankful to Mr. Manuel J. Iturra and Claudio A. Bastías for their technical support in the preparation and characterization of materials.

\section{FUNDING AND ADDITIONAL INFORMATION}

This work was supported by the Center for Biotechnology and Biomedicine Spa (CBB), and by the ANID (ex-CONICYT) PFCHA/Doctorado Nacional/2014-21141016.

\section{CONFLICT OF INTEREST}

"The authors declare that they have no conflicts of interest with the contents of this article."

\section{REFERENCES}

1. Cabal-Hierro, L., and Lazo, P. S. (2012) Signal transduction by tumor necrosis factor receptors. Cell. Signal. 24, 1297-1305

2. Tang, P., Hung, M. C., and Klostergaard, J. (1996) Human pro-tumor necrosis factor is a homotrimer. Biochemistry. 35, 8216-8225

3. Black, R. A., Rauch, C. T., Kozlosky, C. J., Peschon, J. J., Slack, J. L., Wolfson, M. F., Castner, B. J., Stocking, K. L., Reddy, P., Srinivasan, S., Nelson, N., Boiani, N., Schooley, K. A., Gerhart, M., Davis, R., Fitzner, J. N., Johnson, R. S., Paxton, R. J., March, C. J., and Cerretti, D. P. (1997) A metalloproteinase disintegrin that releases tumour-necrosis factor- $\varnothing$ from cells. Nature. $\mathbf{3 8 5}$, 729-733

4. Brenner, D., Blaser, H., and Mak, T. W. (2015) Regulation of tumour necrosis factor signalling: live or let die. Nat. Rev. Immunol. 15, 362-74

5. Smith, R. A., and Baglioni, C. (1987) The active form of tumor necrosis factor is a trimer. $J$. Biol. Chem. 262, 6951-4

6. Tracey, D., Klareskog, L., Sasso, E. H., Salfeld, J. G., and Tak, P. P. (2008) Tumor necrosis 
factor antagonist mechanisms of action: A comprehensive review. Pharmacol. Ther. 117, 244279

7. Bradley, J. R. (2008) TNF-mediated inflammatory disease. J. Pathol. 10.1002/path.2287

8. Kalliolias, G. D., and Ivashkiv, L. B. (2016) TNF biology, pathogenic mechanisms and emerging therapeutic strategies. Nat. Rev. Rheumatol. 12, 49-62

9. Walsh, G. (2018) Biopharmaceutical benchmarks 18. Nat. Biotechnol. 36, 1136-1145

10. Liang, S., Dai, J., Hou, S., Su, L., Zhang, D., Guo, H., Hu, S., Wang, H., Rao, Z., Guo, Y., and Lou, Z. (2013) Structural basis for treating tumor necrosis factor $\alpha(\mathrm{TNF} \alpha)$-associated diseases with the therapeutic antibody infliximab. J. Biol. Chem. 288, 13799-13807

11. Hu, S., Liang, S., Guo, H., Zhang, D., Li, H., Wang, X., Yang, W., Qian, W., Hou, S., Wang, H., Guo, Y., and Lou, Z. (2013) Comparison of the inhibition mechanisms of Adalimumab and Infliximab in treating tumor necrosis factor $\alpha$-associated diseases from a molecular view. J. Biol. Chem. 288, 27059-27067

12. Ono, M., Horita, S., Sato, Y., Nomura, Y., Iwata, S., and Nomura, N. (2018) Structural basis for tumor necrosis factor blockade with the therapeutic antibody golimumab. Protein Sci. 27, 10381046

13. Lee, J. U., Shin, W., Son, J. Y., Yoo, K.-Y., and Heo, Y.-S. (2017) Molecular Basis for the Neutralization of Tumor Necrosis Factor $\alpha$ by Certolizumab Pegol in the Treatment of Inflammatory Autoimmune Diseases. Int. J. Mol. Sci. 18, 228

14. Mukai, Y., Nakamura, T., Yoshikawa, M., Yoshioka, Y., Tsunoda, S. I., Nakagawa, S., Yamagata, Y., and Tsutsumi, Y. (2010) Solution of the structure of the TNF-TNFR2 complex. Sci. Signal. 10.1126/scisignal.2000954

15. Mitoma, H., Horiuchi, T., Tsukamoto, H., and Ueda, N. (2018) Molecular mechanisms of action of anti-TNF- $\alpha$ agents - Comparison among therapeutic TNF- $\alpha$ antagonists. Cytokine.

10.1016/j.cyto.2016.08.014

16. Lim, H., Lee, S. H., Lee, H. T., Lee, J. U., Son, J. Y., Shin, W., and Heo, Y. S. (2018) Structural biology of the TNF $\alpha$ antagonists used in the treatment of rheumatoid arthritis. Int. J. Mol. Sci. 19, $1-14$

17. Kaymakcalan, Z., Sakorafas, P., Bose, S., Scesney, S., Xiong, L., Hanzatian, D. K., Salfeld, J., and Sasso, E. H. (2009) Comparisons of affinities, avidities, and complement activation of adalimumab, infliximab, and etanercept in binding to soluble and membrane tumor necrosis factor. Clin. Immunol. 131, 308-316

18. Shealy, D. J., Cai, A., Staquet, K., Baker, A., Lacy, E. R., Johns, L., Vafa, O., Gunn, G., Tam, S., Sague, S., Wang, D., Brigham-Burke, M., Dalmonte, P., Emmell, E., Pikounis, B., Bugelski, P. J., Zhou, H., Scallon, B. J., and Giles-Komar, J. M. (2010) Characterization of golimumab, a human monoclonal antibody specific for human tumor necrosis factor $\alpha$. MAbs. 2, 428-439

19. Van Schie, K. A., Ooijevaar-De Heer, P., Dijk, L., Kruithof, S., Wolbink, G., and Rispens, T. (2016) Therapeutic TNF Inhibitors can Differentially Stabilize Trimeric TNF by Inhibiting Monomer Exchange. Sci. Rep. 6, 1-10

20. Scallon, B., Cai, A. N. N., Solowski, N., Rosenberg, A. M. Y., Song, X., and Shealy, D. (2002) Binding and Functional Comparisons of Two Types of Tumor Necrosis Factor Antagonists. 301, $418-426$

21. Beatty, J. D., Beatty, B. G., and Vlahos, W. G. (1987) Measurement of monoclonal antibody affinity by non-competitive enzyme immunoassay. J. Immunol. Methods. 100, 173-179

22. Walsh, G. (2018) Biopharmaceutical benchmarks 2018. Nat. Biotechnol. 36, 1136-1145

23. Corti, A., Ghezzi, P., Curnis, F., and Corti, A. (2004) Production and Characterization of Recombinant Human and Murine TNF. Tumor Necrosis Factor. 98, 009-022

24. Alizadeh, A., Hamzeh-Mivehroud, M., Farajzadeh, M., Moosavi-Movahedi, A., and Dastmalchi, S. (2015) A Simple and Rapid Method for Expression and Purification of Functional TNF\&\#945; Using GST Fusion System. Curr. Pharm. Biotechnol. 16, 707-715

25. Jerabek-Willemsen, M., Wienken, C. J., Braun, D., Baaske, P., and Duhr, S. (2011) Molecular Interaction Studies Using Microscale Thermophoresis. Assay Drug Dev. Technol. 9, 342-353 
26. Jerabek-Willemsen, M., André, T., Wanner, R., Roth, H. M., Duhr, S., Baaske, P., and Breitsprecher, D. (2014) MicroScale Thermophoresis: Interaction analysis and beyond. J. Mol. Struct. 1077, 101-113

27. Song, M. Y., Park, S. K., Kim, C. S., Yoo, T. H., Kim, B., Kim, M. S., Kim, Y. S., Kwag, W. J., Lee, B. K., and Baek, K. (2008) Characterization of a novel anti-human TNF-alpha murine monoclonal antibody with high binding affinity and neutralizing activity. Exp. Mol. Med. 40, 3542

28. Yang, T., Wang, Z., Wu, F., Tan, J., Shen, Y., Li, E., Dai, J., Shen, R., Li, G., Wu, J., Wang, L., Wang, H., and Liu, Y. (2010) A variant of TNFR2-Fc fusion protein exhibits improved efficacy in treating experimental rheumatoid arthritis. PLoS Comput. Biol. 10.1371/journal.pcbi.1000669

29. Tran, B. N., Chan, S. L., Ng, C., Shi, J., Correia, I., Radziejewski, C., and Matsudaira, P. (2017) Higher order structures of Adalimumab, Infliximab and their complexes with TNF $\alpha$ revealed by electron microscopy. Protein Sci. 26, 2392-2398

30. Kohno, T., Tam, L. T. T., Stevens, S. R., and Louie, J. S. (2007) Binding characteristics of tumor necrosis factor receptor-Fc fusion proteins vs anti-tumor necrosis factor mAbs. J. Investig. Dermatology Symp. Proc. 12, 5-8

31. Schulz, M., Dotzlaw, H., and Neeck, G. (2014) Ankylosing spondylitis and rheumatoid arthritis: Serum levels of TNF- $\alpha$ and its soluble receptors during the course of therapy with etanercept and infliximab. Biomed Res. Int. 10.1155/2014/675108

32. Arican, O., Aral, M., Sasmaz, S., and Ciragil, P. (2005) Serum levels of TNF- $\alpha$, IFN- $\gamma$, IL-6, IL8, IL-12, IL-17, and IL-18 in patients with active psoriasis and correlation with disease severity. Mediators Inflamm. 2005, 273-279

33. Chen, D. Y., Chen, Y. M., Tsai, W. C., Tseng, J. C., Chen, Y. H., Hsieh, C. W., Hung, W. T., and Lan, J. L. (2015) Significant associations of antidrug antibody levels with serum drug trough levels and therapeutic response of adalimumab and etanercept treatment in rheumatoid arthritis. Ann. Rheum. Dis. 74, 1-9

34. Sanmarti, R., Inciarte-Mundo, J., Estrada-Alarcon, P., Garcia-Manrique, M., Narvaez, J., Rodriguez-Moreno, J., Gomez-Centeno, A., Pascal, M., and Yagüe, J. (2015) Towards optimal cut-off trough levels of adalimumab and etanercept for a good therapeutic response in rheumatoid arthritis. Results of the INMUNOREMAR study. Ann. Rheum. Dis. 74, 2015

35. Daïen, C. I., Daïen, V., Parussini, E., Dupuy, A. M., Combe, B., and Morel, J. (2012) Etanercept concentration in patients with rheumatoid arthritis and its potential influence on treatment decisions: A pilot study. J. Rheumatol. 39, 1533-1538

36. Chiu, Y. L., Rubin, D. T., Vermeire, S., Louis, E., Robinson, A. M., Lomax, K. G., Pollack, P. F., and Paulson, S. K. (2013) Serum adalimumab concentration and clinical remission in patients with Crohn's disease. Inflamm. Bowel Dis. 19, 1112-1122

37. Hinojosa, J., Muñoz, F., and Martínez-Romero, G. J. (2019) Relationship between Serum Adalimumab Levels and Clinical Outcome in the Treatment of Inflammatory Bowel Disease. Dig. Dis. 37, 444-450

38. LAEMMLI, U. K. (1970) Cleavage of Structural Proteins during the Assembly of the Head of Bacteriophage T4. Nature. 227, 680-685

39. Mosmann, T. (1983) Rapid colorimetric assay for cellular growth and survival: application to proliferation and cytotoxicity assays. J. Immunol. Methods. 65, 55-63

\section{FOOTNOTES}


bioRxiv preprint doi: https://doi.org/10.1101/2020.06.21.163824; this version posted June 23, 2020. The copyright holder for this preprint (which was not certified by peer review) is the author/funder, who has granted bioRxiv a license to display the preprint in perpetuity. It is made available under aCC-BY-ND 4.0 International license.

Figures 


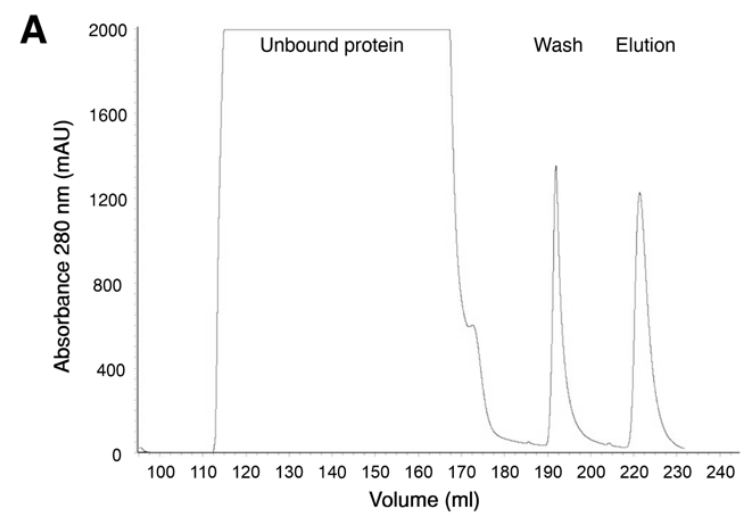

B

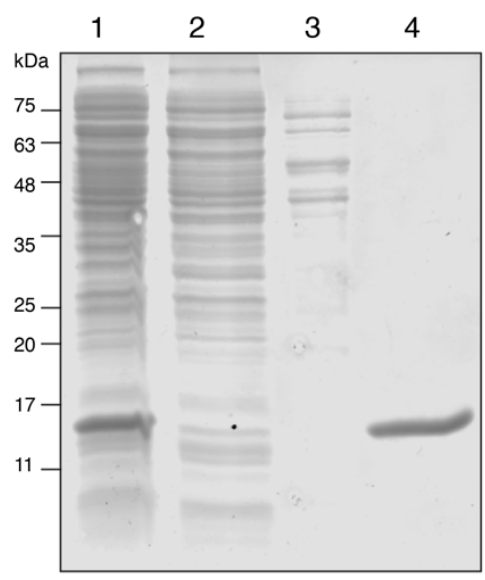

C

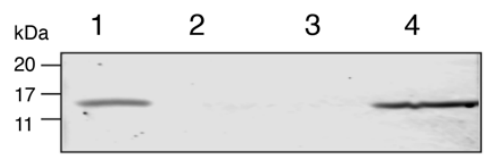

Figure 1. rhTNF $\alpha$ purification from SHuffle ${ }^{\circ}$ T7 Express E. coli by IMAC.

(A) Chromatogram of the purification of rhTNF $\alpha$ by Immobilized-metal affinity chromatography (IMAC). $(\mathrm{B}, \mathrm{C})$ Analysis of fractions collected in the purification process by $15 \%$ SDS-PAGE and Coomassie blue staining (B), and western blot to detect 6xHis tag (C). Lane 1: Input fraction. Lane 2: Flow-through from Ni-NTA affinity column. Lane 3: Wash step. Lane 4: Elution. 

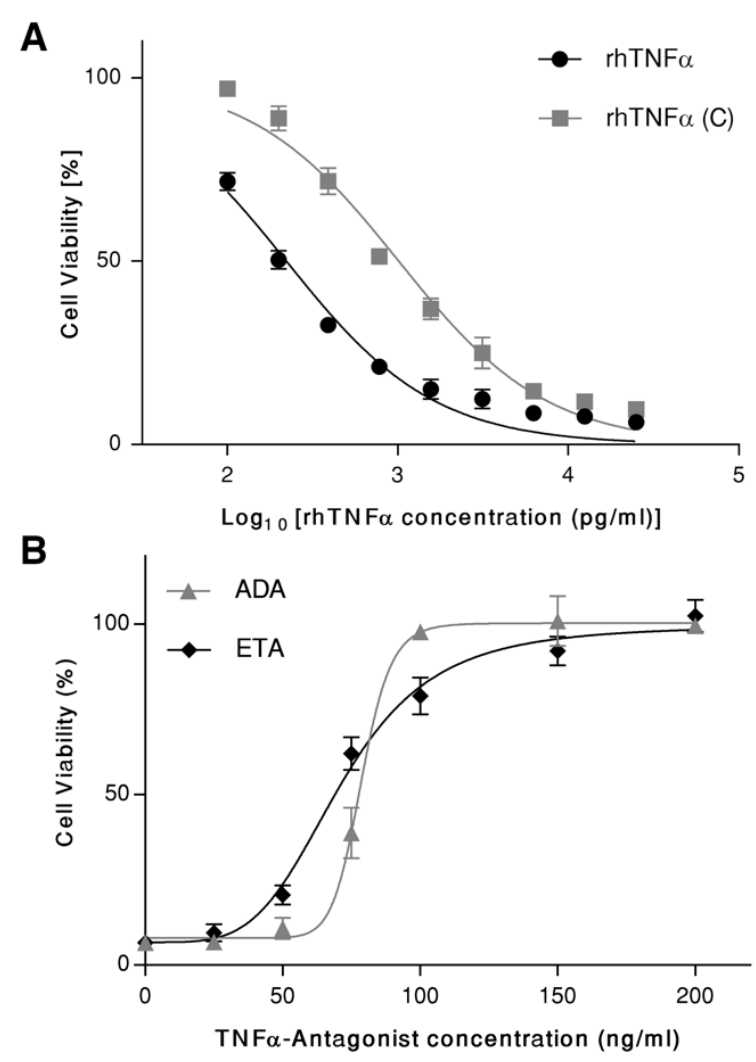

Figure 2. Cytotoxic activity of rhTNF $\alpha$ in L929 cells assay.

(A) L929 cells were treated with RPMI-10\% FBS medium containing variable concentrations of rhTNF $\alpha$ (0-25 ng/ml). After 20, cells viability was determined by MTT assay. $\operatorname{rhTNF} \alpha(\mathrm{C})$ (Merck, Germany) was used as a positive control of activity. The $\mathrm{EC}_{50}$ values for $\operatorname{rhTNF} \alpha(\mathrm{C})$ and $\mathrm{rhTNF} \alpha$ were $1012 \mathrm{pg} / \mathrm{ml}$ and $221 \mathrm{pg} / \mathrm{ml}$ respectively. (B) L929 cells were treated with RPMI-10\% FBS medium containing $25 \mathrm{ng} / \mathrm{ml}$ rhTNF $\alpha$ and different concentrations of Etanercept (ETA) or Adalimumab (ADA). After $20 \mathrm{~h}$, cells viability was determined by MTT assay. The $\mathrm{EC}_{50}$ values for Adalimumab and Etanercept were $78.6 \mathrm{ng} / \mathrm{ml}$ and $71.2 \mathrm{ng} / \mathrm{ml}$ respectively. All data were presented as mean $\pm \mathrm{SD}$ of four replicate wells. Mathematical analysis was performed using Graph Pad Prism 7 software. 
A

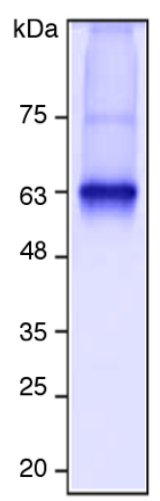

B

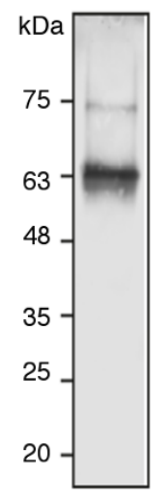

6xHis ADA
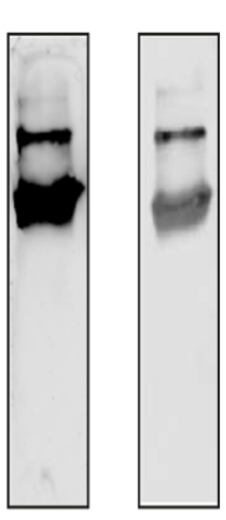

ETA
C
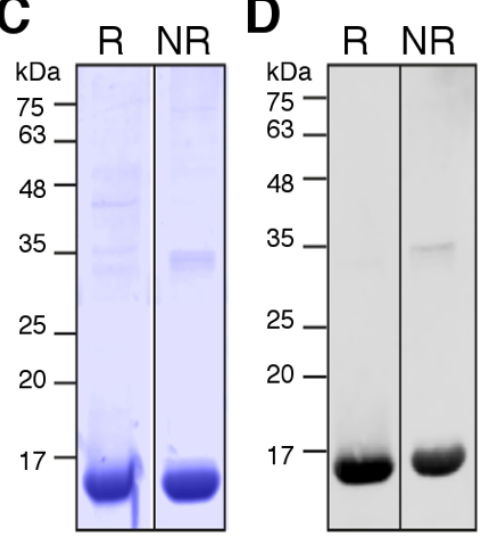

$6 \mathrm{xHis}$

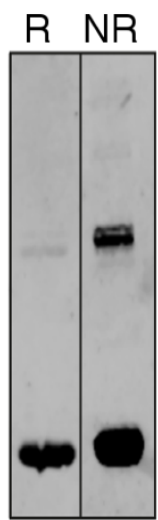

ADA

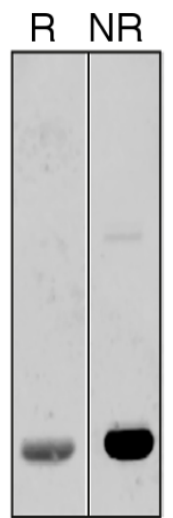

ETA

Figure 3. Native and denaturant electrophoresis of rhTNFa and western blot with Adalimumab and Etanercept.

(A) Native PAGE and Coomassie blue staining of rhTNF $\alpha$. (B) Western blot after native PAGE of rhTNF $\alpha$ to detect the protein using anti-6xHis tag antibody (6xHis), Adalimumab (ADA) and Etanercept (ETA). (C) SDS-PAGE and Coomassie blue staining of rhTNF $\alpha$. (D) Western blot after SDS-PAGE of rhTNF $\alpha$ using anti-6xHis Tag antibody (6xHis), Adalimumab (ADA) and Etanercept (ETA). R: Reducing condition NR: Non-reducing condition. 

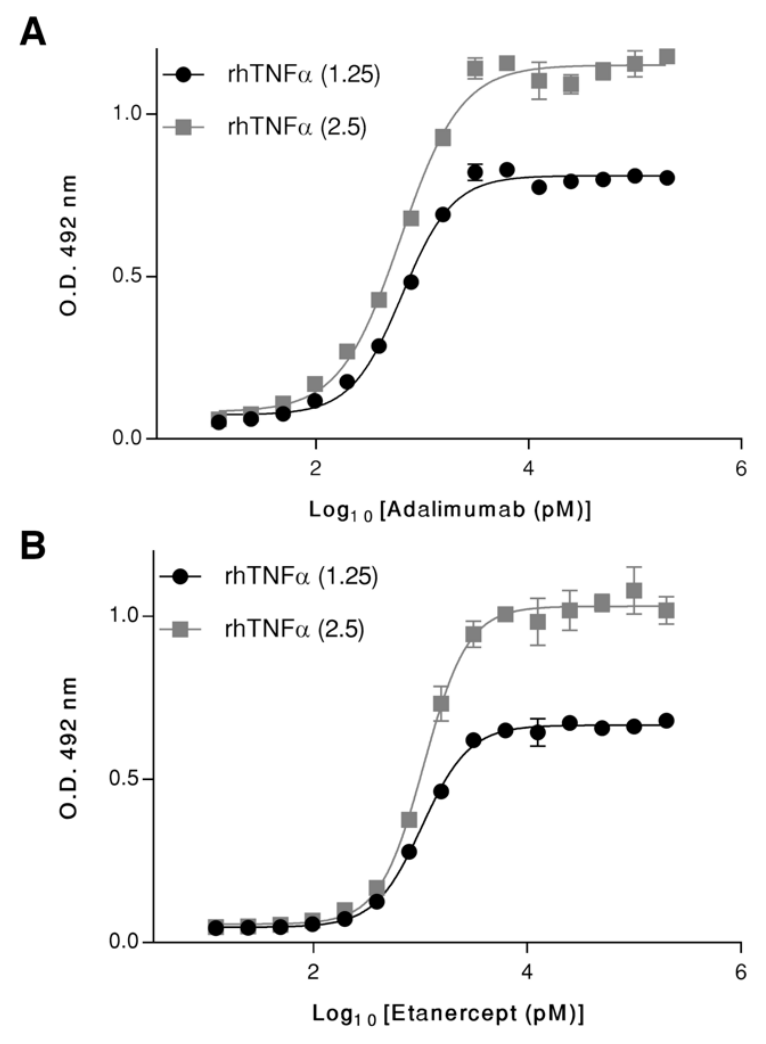

Figure 4. $r$ TNF $\alpha$-TNF $\alpha$ antagonists $\mathrm{K}_{\mathrm{D}}$ determination by a non-competitive enzyme-immunoassay.

(A) Experimental binding curve for Adalimumab at two rhTNF $\alpha$-coating concentrations $(1,25$ and 2,5 $\mu \mathrm{g} / \mathrm{ml}$ ), the calculated antibody concentrations at $\mathrm{OD}_{50}$ were $641 \mathrm{pM}$ and $622 \mathrm{pM}$. The $\mathrm{K}_{\mathrm{D}}$ for the interaction of rhTNF $\alpha$-Adalimumab was $1.32 \mathrm{nM}$. (B) Experimental binding curve for Etanercept at two rhTNF $\alpha$-coating concentrations $(1,25$ and $2,5 \mu \mathrm{g} / \mathrm{ml})$, the calculated antibody concentrations at $\mathrm{OD}_{50}$ were $1035 \mathrm{pM}$ and $1072 \mathrm{pM}$. The $\mathrm{K}_{\mathrm{D}}$ for the interaction of rhTNF $\alpha$-Etanercept was $1.99 \mathrm{nM}$. All data were presented as mean \pm SD of three replicate wells. Mathematical analysis was performed using Graph Pad Prism 7 software. 
A

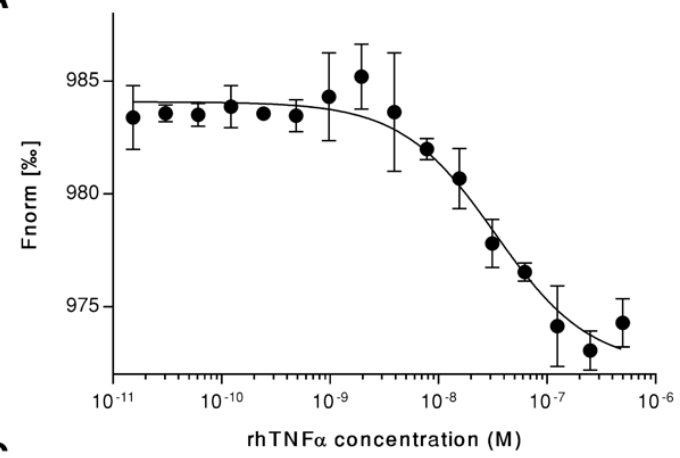

C

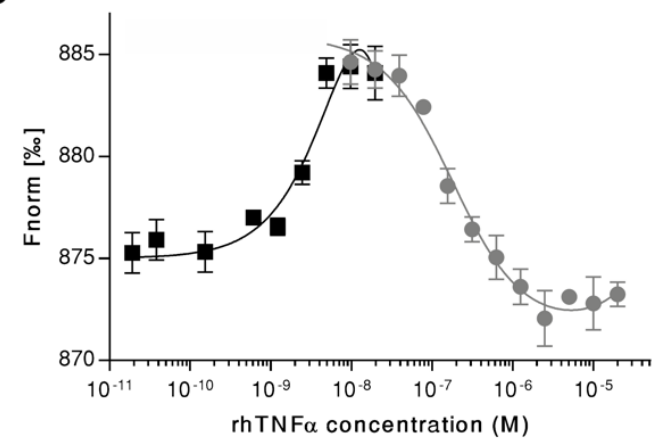

B

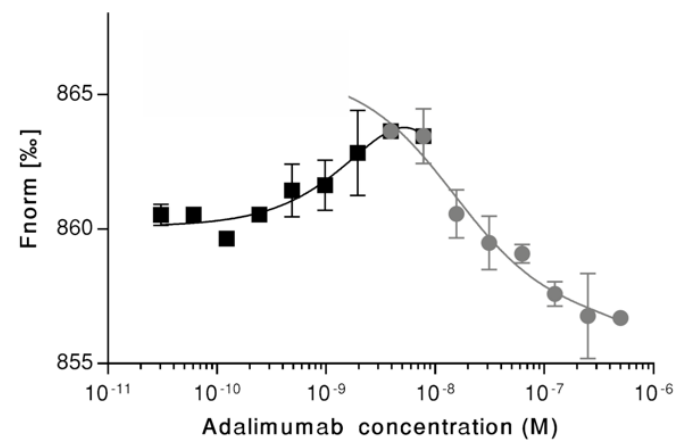

D

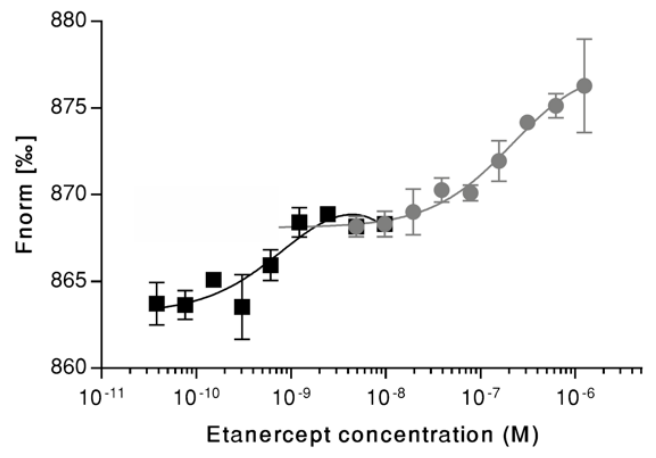

Figure 5. rhTNF $\alpha$-TNF $\alpha$ antagonists binding studies by microscale thermophoresis.

(A) Binding curve of labeled Adalimumab with rhTNFa. Adalimumab (NT-647) was constant 5nM while the concentration of rhTNF $\alpha$ was varied between $500 \mathrm{nM}-30.5 \mathrm{pM}$. The MST traces were analyzed and the $\mathrm{K}_{\mathrm{D}}$ of the interaction was $29.6 \pm 7.4 \mathrm{nM}$. N=3. (B) Binding curve of labeled rhTNF $\alpha$ with Adalimumab. The MST experiment was performed at constant concentration of labeled rhTNF $\alpha(2 \mathrm{nM})$ and variable concentration of Adalimumab between $30.5 \mathrm{pM}$ and $1 \mu \mathrm{M}$. The MST traces were analyzed and two binding curves were detected. The first curve had a $\mathrm{K}_{\mathrm{D}}$ value of $100.2 \pm 187.5 \mathrm{pM}$, and the second curve had a $K_{D}$ value of $21.00 \pm 9.43 \mathrm{nM}$. N=2. (C) Binding curve of labeled Etanercept with rhTNFa. In the MST experiment, the concentration of labeled Etanercept was constant at $2 \mathrm{nM}$, while the concentration of the non-labeled rhTNF $\alpha$ was varied between $19.1 \mathrm{pM}$ and $20 \mu \mathrm{M}$. The MST traces were analyzed and two binding curves were detected. The first curve had a $\mathrm{K}_{\mathrm{D}}$ value of $1.25 \pm 0.78 \mathrm{nM}$, and the second curve had a $K_{D}$ value of $175.5 \pm 38.2 \mathrm{nM}$. N=3. (D) Binding curve of labeled rhTNF $\alpha$ with Etanercept. The experiment was performed using labeled TNF $\alpha$ at $2 \mathrm{nM}$, and the Etanercept concentrations were variable between $38.1 \mathrm{pM}$ and $1.25 \mu \mathrm{M}$. The MST traces were analyzed and two binding curves were detected. The first curve had a $K_{D}$ value of $317.8 \pm 325.3 \mathrm{pM}$, and the second curve had a $\mathrm{K}_{\mathrm{D}}$ value of $183.5 \pm 23.4$ nM. N=3. All MST experiments were performed using the Monolith NT.115 Pico (NanoTemper Technologies) at $25^{\circ} \mathrm{C}$ and the results were analyzed in the software M.O. Affinity Analysis v.2.3 (NanoTemper Technologies). The charts were generated in Graph Pad Prism 7 software. All data were presented as mean $\pm \mathrm{SD}$ of replicates. 


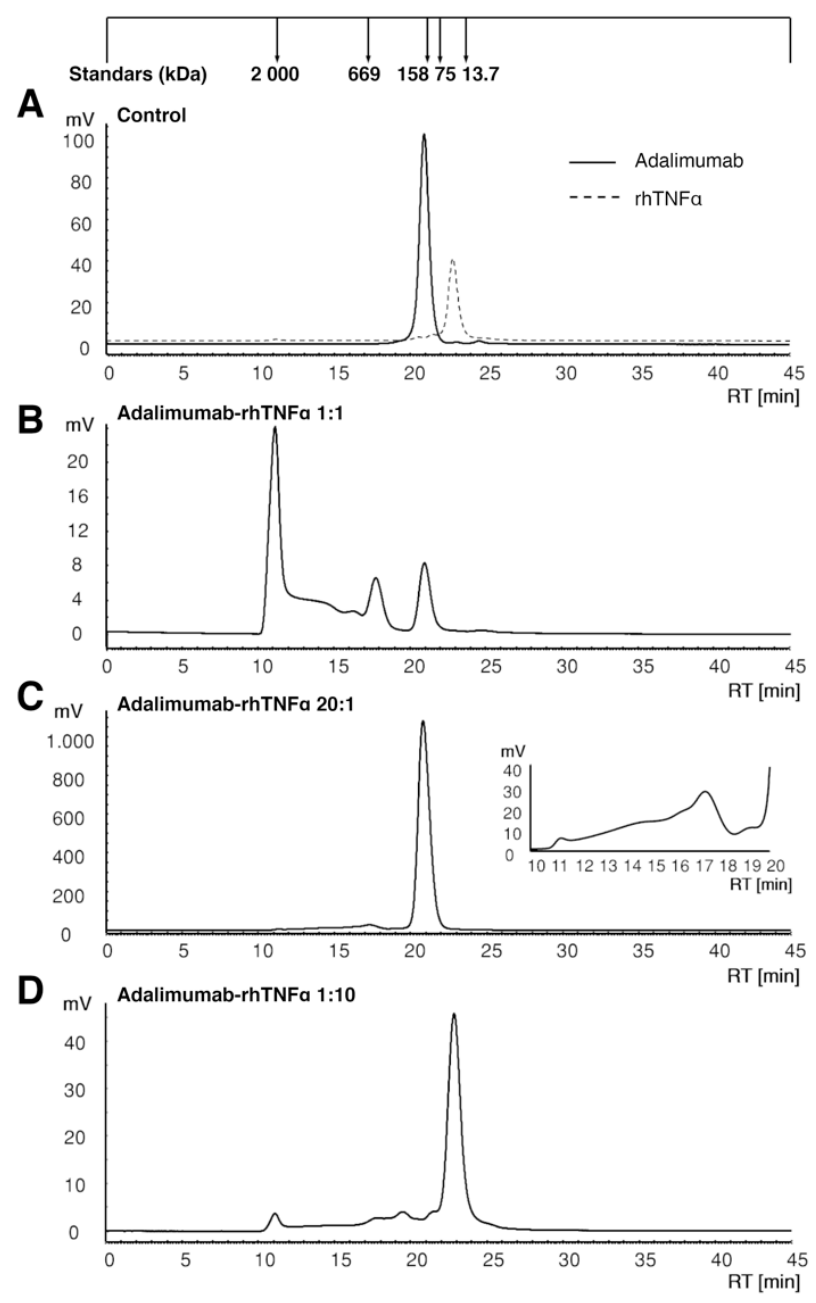

Figure 6. rhTNF $\alpha$-Adalimumab complexes analysis by SEC-HPLC.

(A) Controls. Samples of Adalimumab and $\operatorname{rhTNF} \alpha$ at $6.7 \mu \mathrm{M}$ were analyzed independently. (B) Adalimumab-rhTNF $\alpha$ 1:1. Analysis of a solution containing Adalimumab $(6.7 \mu \mathrm{M})$ and $\operatorname{rhTNF} \alpha(6.7 \mu \mathrm{M})$. (C) Adalimumab-rhTNF $\alpha$ 20:1. Analysis of a solution containing Adalimumab $(670 \mu \mathrm{M})$ and $\operatorname{rhTNF} \alpha$ $(6.7 \mu \mathrm{M})$. (D) Adalimumab-rhTNF $\alpha$ 1:10. Analysis of a solution containing Adalimumab $(3.35 \mu \mathrm{M})$ and rhTNF $\alpha(33.5 \mu \mathrm{M})$. All separation experiments were performed on a Jasco HPLC system with a TSK Gel G4000SW $\mathrm{XL}_{\mathrm{XL}}$ column. A flow rate of $0.5 \mathrm{ml} / \mathrm{min}$ and a $50 \mathrm{mM}$ phosphate- $300 \mathrm{mM} \mathrm{NaCl}$ buffer (pH 7.5) were used for the analysis. The system was calibrated using Blue Dextran 2000 (2.000 kDa), Thyroglobulin (669 kDa), Aldolase (158 kDa), Conalbumin (75 kDa) and Ribonuclease A (13.7 kDa). 

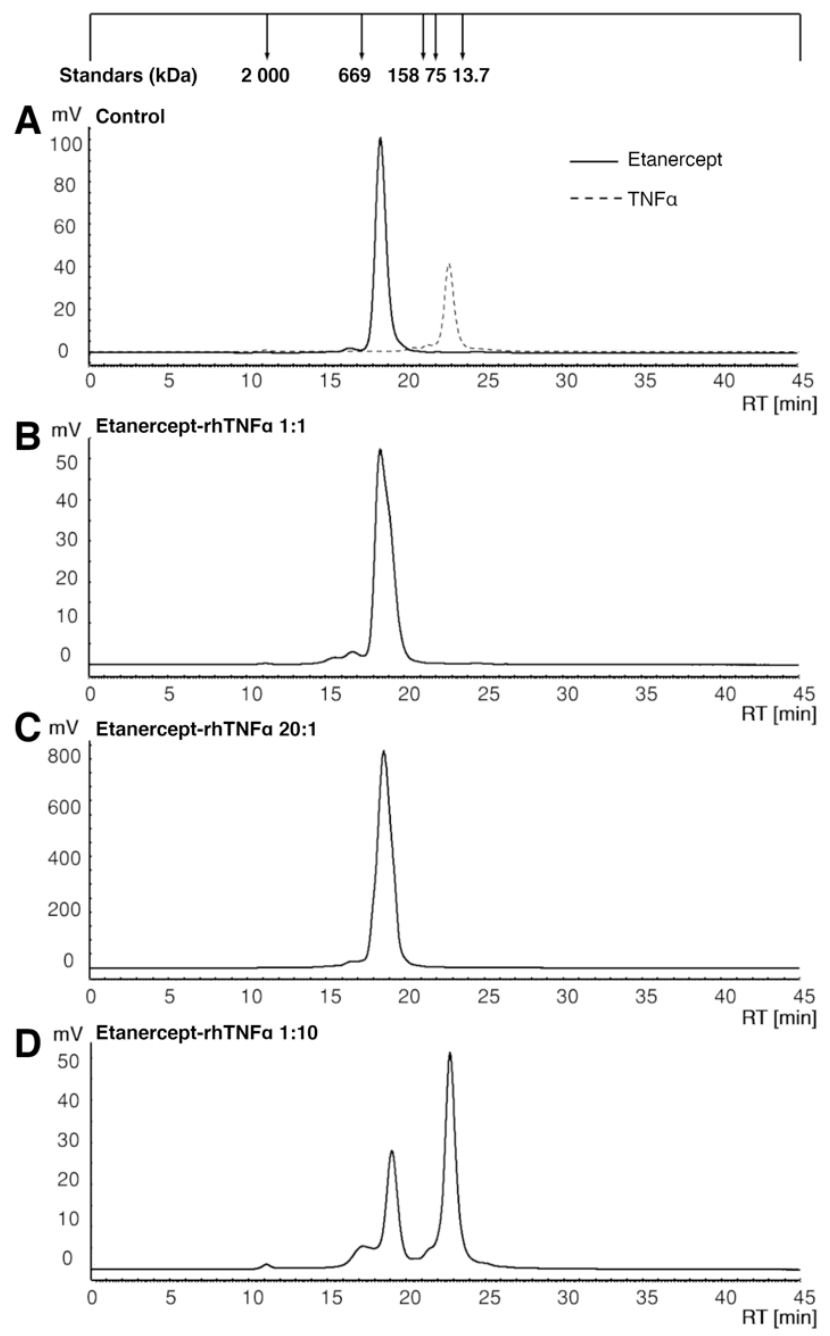

Figure 7. rhTNF $\alpha$-Etanercept complex analysis by SEC-HPLC.

(A) Controls. Samples of Etanercept and rhTNF $\alpha$ at $6.7 \mu \mathrm{M}$ were analyzed independently. (B) EtanerceptrhTNF $\alpha$ 1:1. Analysis of a solution containing Etanercept $(6.7 \mu \mathrm{M})$ and $\operatorname{rhTNF} \alpha(6.7 \mu \mathrm{M})$. (C) EtanerceptrhTNF $\alpha$ 20:1. Analysis of a solution containing Etanercept $(670 \mu \mathrm{M})$ and $\operatorname{rhTNF} \alpha(6.7 \mu \mathrm{M})$. (D) Etanercept-rhTNF $\alpha$ 1:10. Analysis of a solution containing Etanercept $(3.35 \mu \mathrm{M})$ and $\operatorname{rhTNF} \alpha(33.5 \mu \mathrm{M})$. All separation experiments were performed on a Jasco HPLC system with a TSK Gel G4000SW ${ }_{\mathrm{XL}}$ column. A flow rate of $0.5 \mathrm{~mL} / \mathrm{min}$ and a $50 \mathrm{mM}$ phosphate- $300 \mathrm{mM} \mathrm{NaCl}$ buffer (pH 7.5) were used for the analysis. The system was calibrated using Blue Dextran 2000 (2.000 kDa), Thyroglobulin (669 kDa), Aldolase $(158 \mathrm{kDa})$, Conalbumin $(75 \mathrm{kDa})$ and Ribonuclease A $(13.7 \mathrm{kDa})$. 
A
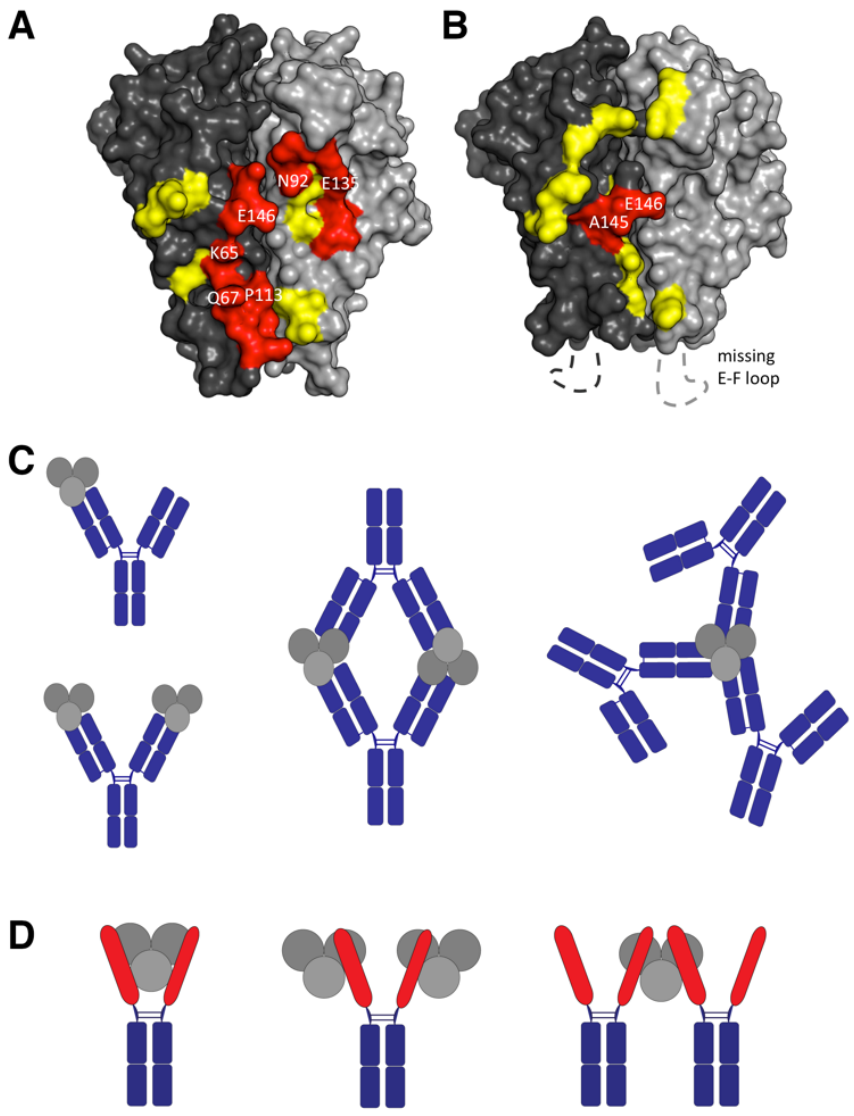

Figure 8. $\mathrm{TNF} \alpha$ and $\mathrm{TNF} \alpha$-antagonist interactions.

(A, B) Tridimensional representation of $\mathrm{TNF} \alpha$, monomers are presented in different shades of grey and the interfaces of the interaction with Adalimumab (A) and TNFR2 (B) are shown in yellow and red. The red surface are the sequences postulates as lineal epitopes. (C) Illustration of the TNF $\alpha$-Adalimumab complexes. (D) Illustration of the proposed TNF $\alpha$-Etanercept complexes. 